International Journal on Integrating Technology in Education (IJITE) Vol.3, No.2, June 2014

\title{
A Historical Perspective of the Evolution OF TECHNOLOGY EDUCATION
}

\author{
Heshium Lawrence and Mark Miller \\ Department of HRD and Technology, Tyler, TX
}

\begin{abstract}
As technology evolves and becomes more complex over time, so must the training for those involved in creating it. This article reviews the various programs that were developed throughout America's history to prepare individuals for designing and working with the technology that inevitably made it a great nation. The necessities that warranted each program are discussed as well as the reasons for each of their demise. This article also addresses the factors facing technology-based education and the importance of its future.
\end{abstract}

\section{KEYWORDS}

Technology Education, Industrial Arts, Technical Education, Industrial Technology, Manual Training

\section{TECHNICAL EDUCATION}

The introduction of technology education can be traced back to Lois Coffey Mossman and Frederic Gordon Bonser who had the greatest influence on the origins of what is now known as technology education [1]. Technology education in the United States was presumed to have been founded in the early twentieth century as industrial arts but there are historic roots that date the field back much further than that.

According to Cunningham [2], the first recognizable technical education programs did not appear until the last decade of the nineteenth century and there were only two schools that had the programs, "Pratt Institute in 1895 and Bradley Polytechnic Institute in 1897" (pp.27-28). The curriculum of technology education was "designed to meet the needs of mature students who planned to enter industrial employment after graduation" [2] (p. 28). It is interesting to note that during the period of mechanization, which was during the late 1800's to the mid 1950's, technology programs existed in only six institutions of higher education which were Bradley University, Alabama A. \& M. College, West Virginia State College, Kansas State College, Arizona State University, and Southern Illinois University [2].

\section{MANUAL TRAINING}

The concept of industrial arts was conceived from technology education and evolved from the term manual training which was not "introduced into this country until 1880" [3] (p. 3). Calvin Woodward, the "father of manual training" [4] (p. 20), established the famous St. Louis Manual Training School [5]. Prior to Woodward establishing the St. Louis Manual Training School, he opened the country's first manual training high school in 1880, known as "The Manual Training School of Washington University" [6] ( p. 2-3). 
International Journal on Integrating Technology in Education (IJITE) Vol.3, No.2, June 2014

Woodward believed that the skills the students acquired would help them deal with people, places, and things. Manual training had a threefold purpose in the nineteenth century, "keeping boys in school", "provide vocational skills," and "develop leisure-time interests" [7] (p. 8). Manual training later evolved to include objectives which incorporated instruction in the fundamental principles, processes and materials of industry. Over the years Americans began to take a "learning by doing approach" [8] (p. 574) and manual training began to take some criticism. It was stated that manual training was too official, too unyielding, and not truly liberal because it "confined the pupil to exercises in narrow fields and ignored relationships with the sciences" [6] (p. 3).

Manual training did not provide support for the work that the students were being asked to do nor provide relevance to what they were doing. There was no structure for the student to express themselves on an individual basis and not only did manual training discourage initiative but it also focused on the product that they were producing instead of whether they actually understood what he/she was doing. Manual training only taught tool use. Bonser and Mossman's observation of manual training initiated them to develop a detailed system of industrial education. Their detailed system became the foundation for industrial education in the United States and has been the theoretical basis for over 70 years [9] [1] [10]. Manual training morphed into manual arts, which "indicates the content of several subjects which are included in a division of the school dealing with industrial work [11] (p. 5). The concept of manual arts influenced the development of other forms of industrial education but was short lived; Industrial Arts was the third influence of technology education.

\section{INDUSTRIAL ARTS}

Industrial Arts was a product of the progressive movement. The progressive education movement revealed weaknesses in the existing public school program. Emphasis was placed on the subject matter in Industrial Arts and the student was not considered an individual nor given any consideration. According to Luetkemeyer [12], "[students] was thought qualified to attend public school only if they were capable of fitting a rigid, formalized set of educational standards" (p. 19). Subject-matter disciplines include but are not limited to academics such as reading, writing, arithmetic, history or science. John Dewey, William Kilpatrick and Francis Parker along with other educators, wanted students to have a more practical approach to learning. Dewey and other educators, who were against traditional schooling, formed The Progressive Education Association in the early twentieth century to change the normal structured classroom and divert from the subject matter curriculum to a curriculum that used activities, experiences, problem solving, and projects to stimulate the mind [13] (p. 114).

Industrial Arts having been influenced by manual training and the progressive movement focused its content on both the student and the subject matter. Industrial Arts is "an aspect of general education concerned with satisfying man's innate desire to construct projects with tools and materials" [3] (p. 4). General education refers to the process or art of communicating knowledge, skill and judgment. The term and concept of Industrial Arts did not get is recognition until Frederick Bonser, in 1909 issued a pamphlet entitled Industrial Education, which outlined the "social-industry theory" of Industrial Arts. "Industrial arts is a study of the changes made by man in the forms of material to increase their values, and of the problems of life related to these changes" [14] (p. 5). Industrial Arts programs covered a range of skills rather than a specific activity. In essence, Industrial Arts was an educational agenda which focused on the fabrication 
of objects or useful equipment by wood and/or metal using an assortment of hand, power, or machine tools.

The aims and purposes of Industrial Arts was for the student to acquire an understanding of the industrial field in which man uses those materials to improve his/her daily life. In acquiring that understanding, the student would appreciate the influence that industry has on his/her life. Since Industrial Arts is a hands-on curriculum area, the student would learn how to use those tools that would help and aid in constructing objects that improve his/her living conditions as well as build up an understanding about safety that can be applied to social development.

When Russia launched its first Sputnik into orbit in 1957, it was a blow not only to government agencies but the school systems as well. It was the fact that the Russians were the first to accomplish such a task that lead to "an outcry that our schools were lagging behind those in Russia, as they had produced better scientists." [3] (p. 8). American educators began to look at its educational policies and standards and noticed a few problems.

These problems ranged from "the rapid development of new scientific principles, their application to industry, their implication and translation into shop and laboratory experiences" and "the unusual stress being placed on academic subject matter at the expense of manipulative activities" to "further the need for improved methods of recruitment, in order to attract to the profession more young men with mechanical aptitude, technical interest and superior academic ability" and "the need for a periodic review of the college undergraduate programs in Industrial Arts teacher education and a clarification and improvement of the graduate program." [3] (pp. 1112). The problems mentioned above affected the standards of Industrial Arts teacher education as well as incorrect notions that were being discussed about Industrial Arts which portrayed the idea that the concept of practical or applied area of study is inferior to the theoretical or basic area of study. It was because of some of those notions and the problems that Industrial Arts began to die out. The educational system in America had gone through thirty-four years of evolving technology education, each system having its own unique strengths and influences. Table 1 depicts the three systems of technology education over the course of those thirty-four years [6] (p. 12).

Table 1 Systems of Technology Education

\begin{tabular}{|c|c|c|}
\hline Manual Training & Manual Arts & Industrial Arts \\
\hline Inception: 1876 & 1896 & 1910 \\
\hline $\begin{array}{l}\text { Influences: } \\
\text { Della Voss, Runkle, } \\
\text { Woodward }\end{array}$ & Bennett, Salomon, Griffith & Bonser, Dewey, Bigelow \\
\hline $\begin{array}{l}\text { Skills: Artisan basis, tool } \\
\text { mastery }\end{array}$ & Craft basis, "Technics" & $\begin{array}{l}\text { Individual } \\
\text { "Development" }\end{array}$ \\
\hline Methods: Dictated exercises & $\begin{array}{l}\begin{array}{l}\text { Assignment of useful artistic } \\
\text { projects }\end{array} \\
\text { a }\end{array}$ & $\begin{array}{l}\text { Projects and individual } \\
\text { creativity }\end{array}$ \\
\hline $\begin{array}{l}\text { Content largely involved: } \\
\text { Work in wood; Mechanical } \\
\text { drawing }\end{array}$ & $\begin{array}{l}\text { Arts: Graphic, plastic, textile, } \\
\text { mechanical, bookmaking }\end{array}$ & 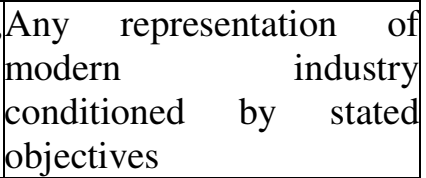 \\
\hline
\end{tabular}




\begin{tabular}{|c|c|}
\hline End functioning: In itself & \begin{tabular}{|l|l|} 
Avocational, nice to have done, & Exploration, development \\
development of appreciation for & of personal-social traits, \\
guidance, & consumer \\
the crafts & $\begin{array}{ll}\text { education } & \text { scientific } \\
\text { evidence and criteria }\end{array}$ \\
\end{tabular} \\
\hline $\begin{array}{l}\text { Basis of truth: Authority } \\
\text { Centers in teacher } \\
\text { Unit-shop }\end{array}$ & $\begin{array}{l}\text { Scientific evidence and } \\
\text { criteria } \\
\text { Centers in pupil } \\
\text { Laboratory of industries or } \\
\text { Unit-shop }\end{array}$ \\
\hline
\end{tabular}

Industrial Arts becomes distinctly exclusive by comparison. It shows maturity in the area of technology education and displays the concept of professionalism. "Industrial Arts emphasizes in addition the all-round arts of industry rather than just manipulative or "'manual"" aspects of artistic construction implied in the term Manual Arts" [15] (p. 27). Industrial Arts was displacing the historical but narrower term Manual Training yet in the same content area, has the same significance as the term Manual Arts. Change began to take place and Americans began to look at a way to redefine the area of technology education; partly due to the bad rapport that Industrial Arts was starting to receive because of the changes occurring in industry as well as the need for those graduating in Industrial Arts to have some knowledge of management.

\section{INDUSTRIAL TECHNOLOGY}

The impact that technology had on industrial productivity and the sudden growth of the use of technology became apparent during the post-World War II period. The demand for professional industrial personnel with higher education, technical application skills, and leadership qualities increased as engineering programs offered less laboratory application courses [16]. In the mid to late 1960's, "universities realized that their industrial arts graduates were often going into industry rather than teaching" [17] ( $\mathrm{p} \mathrm{1)}$. Because of this, over 125 representatives from 58 institutions unanimously voted to organize into a formal body entitled the National Association of Industrial Technology (NAIT) on October 27, 1967 [18]. This organization represented the new discipline of industrial technology that evolved from industrial arts. Charles Keith [17], who is recognized as the founder of industrial technology, noted that, "The evaluation of the industrial technology curriculum continued as follow-up studies on graduates and their employers indicated that in addition to technical competency there was also a need for management and human relation skills (p. 1).

Many industrial technology programs at that time were exact duplicates of industrial arts programs with the exception that students were required to take five business courses in their last semester in lieu of student teaching as was the case at the institution where one of these authors earned his degree.

While industrial arts programs concentrated on technology and psychology, industrial technology programs united the facets of technology and management. Industrial technology is defined as "a field of study designed to prepare technical and/or management oriented professionals for employment in business, industry, education, and government" [19] (p. 1). It should be noted that 
International Journal on Integrating Technology in Education (IJITE) Vol.3, No.2, June 2014

there is overlap between the disciplines as noted in the definition of industrial technology as being a field of study that also prepares individuals for employment in education along with business, industry and government.

As the demand for industrial technology majors escalated from the late 1960's to the present, it did so at the expense of industrial arts teacher education program enrollments. According to [20], from 1970 to 1990 institutions with both industrial arts and industrial technology programs saw a $72.7 \%$ decline in the enrollment of their industrial arts teacher preparation programs while industrial technology programs grew by over $700 \%$.

\section{TECHNOLOGY EDUCATION}

As industrial arts teacher preparation program enrollments dwindled throughout the 1970's, a new direction for the discipline was spearheaded in the early 1980's to help counteract this decline. The International Technology Education Association (ITEA) became the official name for the professional organization in the year 1985 [21]. From that time on, technology education became the new name for most industrial arts programs across the country.

Daugherty and Wicklein [22] noted that "The technology education discipline has undergone revolutionary changes in the past decade" and also noted that "professionals in the field have called for a discipline more closely aligned with mathematics and science" as have Maley [23], Lauda [24] and Welty [25]. In March of 1990, President Bush and the nation's governors developed a set of goals to counteract perceived problems in the country's educational system [26]. One of their goals was to increase the mathematics and science proficiency of America's student body [27]. Barry Stern [27], who was then the Deputy Assistant Secretary of Vocational and Adult Education of the U.S. Department of Education, noted that technology education was one of the ways to improve mathematics and science achievement as well as the overall educational performance of students.

ITEA's strategic plan included the establishment of technology education as the primary discipline for integrating curriculum towards the advancement of technology literacy so the goals developed by the President and governors were well received by technology educators [28]. Moreover, in the year 2000, ITEA released their Standards for Technological Literacy: Content for the Study of Technology which listed a means for integrating technology literacy from kindergarten to the $12^{\text {th }}$ grade [21]. These standards have had several iterations over the years and ITEEA also prepared other publications pertaining to the preparation of teachers, program curricula, and the means for assessing students' technological literacy. With the continued Federal emphasis on improving science, technology, engineering, and mathematics (STEM) education in order to meet the national need for a competitive workforce, ITEA changed its name in 2010 to the International Technology and Engineering Educators Association [29]. The ITEEA organization has over 35,000 members in over 45 countries.

\section{ConCluding Remarks}

As technology continues to be an integral part of our everyday lives, the need for technology education becomes ever more crucial. The Federal government stresses the importance of a competitive workforce by annually funding STEM initiatives for millions of dollars as well as supporting two year college technology programs for the purpose of retraining unemployed 
workers with technological skills currently in demand. Technology education is a key ingredient to America's economic success as a nation and is as important as it was when industrial arts education prepared millions for manufacturing-related jobs that later propelled the United States to become the greatest nation in the world by the late 1940's. Technology education will always be one of the essential elements to America's vitality and must continue to adapt to change and overcome challenges so the nation can maintain its status as a global leader and superpower.

\section{REFERENCES}

[1] Foster, P. N. (1995). The founders of industrial arts in the US [Electronic version]. Journal of Technology Education, Vol. 7, No.1, pp 1-12.

[2] Cunningham, B. M. (1969). Technological developments and industrial technology. In C. T. Dean \& N. A. Hauer (Eds.), Industrial technology education: Relationships of 4-year technology programs with technical training, engineering and industrial arts teacher education (p. 28). Bloomington, IL: American Council on Industrial Arts Teacher Education.

[3] Sotzin, H. A. (1961). The scope of industrial arts. In R. P. Norman \& R. C. Bohn (Eds.), Graduate study in industrial arts (p. 3-12). Bloomington, IL: American Council on Industrial Arts Teacher Education.

[4] Miller, R., \& Smalley, L. (1963). Selected reading in industrial arts. Bloomington, IL: McKnight \& McKnight.

[5] Coates, C. P. (1923). History of the manual training school of Washington University. Bureau of Education Bulletin, No. 3.

[6] Olson, D. W. (1963). Industrial arts and technology. Englewood Cliffs, NJ: Prentice-Hall.

[7] Gerbracht, C., \& Babcock, R. (1969). Elementary school industrial arts. New York: Bruce.

[8] Butts, R. F. (1955). A cultural history of western education. New York: McGraw-Hill.

[9] Foster, P. N. (1994). Technology education: AKA industrial arts [Electronic version]. Journal of Technology Education, Vol. 5, No. 2, pp 15-30.

[10] Foster, P. N. (1997) Lessons from history: Industrial arts/technology education as a case [Electronic version]. Journal of Vocational and Technical Education, Vol. 13, No. 2, pp 1-12.

[11] Crawshaw, F. D., \& Varnum, W. H. (1918). Standards in manual arts, drawing, and design. Madison: The University of Wisconsin.

[12] Luetkemeyer, J. F. (1968). Introduction to the yearbook. In J. F. Luetkemeyer (Ed.), A Historical Perspective of Industry, 17th Yearbook of the American Council on Industrial Arts Teacher Education (p.21). Bloomington, IL: American Council on Industrial Arts Teacher Education.

[13] Levine, D., \& Ornstein, A. (2006). Foundations of education (9th ed., p. 101). Boston, MA: Houghton Mifflin Company.

[14] Bonser, F. G., \& Mossman, L. C. (1923). Industrial arts for elementary schools. New York: MacMillan.

[15] Warner, E. W., Bollinger, E., \& Hutchinson, H. H. (1933). The terminological investigation of professional and scientific terms from the literature of vocational and practical arts education, Vol. 17, No. 2, pp 1-45.

[16] Keith, C.W. \& Talbott, L. (1991). History of Industrial Technology. Ann Arbor, MI: National Association of Industrial Technology.

[17] Keith, C. W. (1986). NAIT history (available from the National Association of Industrial Technology, 3300 Washtenaw Avenue, Suite 200, Ann Arbor, MI 48104).

[18] Mindy, G. (2004). The future history of industrial technology [Electronic version]. Journal of Industrial Technology, Vol. 20, No. 1, pp 1-6.

[19] National Association of Industrial Technology. (1997). Industrial technology accreditation handbook. Ann Arbor, MI: Author.

[20] Volk, K.S. (1993). Enrollment trends in industrial arts/technology education from 1970-1990 [Electronic version]. Journal of Technology Education, Vol. 4, No. 2, pp 1-10. 
International Journal on Integrating Technology in Education (IJITE) Vol.3, No.2, June 2014

[21] International Technology and Engineering Educators Association (2011). Publications. [WWW page]. URL http://www.iteea.org/Publications/publications.htm

[22] Daugherty, M. K., \& Wicklein, R. C. (1993). Mathematics, science, and technology teachers' perception of technology education [Electronic version]. Journal of Technology Education, Vol. 4, No. 2, pp 1-9.

[23] Maley, D. (1985). Issues and trends in technology education. Proceedings of Technology Education Symposium VII. California, PA: California University of Pennsylvania, 3-14.

[24] Lauda, D. (1989). Tech ed: Its place in the secondary school. NASSP Bulletin, Vol. 73, No. 519, pp 13.

[25] Wetly, K. (1990). Making it relevant. Vocational Education Journal, Vol. 65, No. 7, pp 30-33.

[26] Miller, J. (1990, March 14). Small group's role in goal setting provides clues to education policy making. Education Week, Vol. 9, No. 25, pp 1-14.

[27] Stern, B. (1991). Technology education as a component of fundamental education: Part two. The Technology Teacher, Vol. 50, No. 5, pp 9-12.

[28] International Technology Education Association (1990). The ITEA strategic plan. Reston, VA.

[29] International Technology and Engineering Educators Association (2012). The Council on Technology Teacher Education (CTTE) changes its name to the Council on Technology and Engineering Teacher Education $\quad$ (CTETE). 2 page]. URW http://www.iteea.org/Resources/PressRoom/2012/May/CTTE\%20Name\%20Change\%20Press\%20Rele ase $\% 20(2)$.pdf

\section{Authors}

Heshium Lawrence is an Assistant Professor at The University of Texas at Tyler in the Department of Human Resource Development and Technology. He currently teaches undergraduate and graduate courses in Six Sigma, Total Quality Management, and Project Management. He has research experience in the pedagogy of undergraduate students in Industrial Technology programs and is a certified lean six sigma black belt. He has a membership in the Association of Technology, Management, and Applied Engineering (ATMAE) where he serves as the commissioner of the Lean Six Sigma committee and Vice President of the student division.

Mark R. Miller is a professor of technology and the coordinator for the Industrial Technology and Industrial Management programs in the Department of Human Resource Development \& Technology at The University of Texas at Tyler. Dr. Miller has authored or co-authored more than 40 technical books and numerous technical articles. He currently serves as the chairman of the ATMAE Board of Certification in which he has assisted with the development of four new exams. Dr. Miller is also a certified lean six sigma black belt and has received numerous service awards throughout his career.
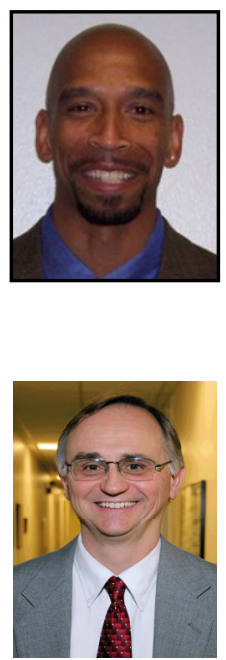